\title{
Role of Cocoa Clones and Endophyte Fungi in Controlling VSD Disease in The Field
}

\author{
Muhammad Taufik ${ }^{1 *}$, Asniah, Muhammad Botek, Rahayu M dan Arifin Tasrif \\ ${ }^{1}$ Department of Crop Protection, Faculty of Agriculture, Universitas Halu oleo, Kendari 93232, Southeast \\ Sulawesi, Indonesia \\ Bogor Agricultural Development Polytechnic, Bogor 16001 \\ *Corresponding Author: taufik24@yahoo.com
}

Received April 15, 2021; revised May 31, 2021; accepted June 30, 2021

\begin{abstract}
The fungus Ceratobasidium theobromae is the cause of vascular streak dieback (VSD) in cocoa. VSD disease can cause death in susceptible clones by more than 59\%. The use of resistant cocoa clones and endophytic fungi can be an alternative for VSD disease control. The research objective was to evaluate cocoa clones and endophytic fungi to control VSD in the field. The experimental design used was a randomized block design with a factorial pattern. The first factor was cocoa clones, which consisted of clones 45 (K1) and 25 (K2), and the second factor was several types of endophytic fungi. The results showed an interaction between cacao clones and endophytic fungi isolates on the height and number of cocoa leaves. The two cacao clones tested could be naturally infected by $C$. theobromae without endophytic fungi, with disease incidence of VSD 5, 21\% in K1, and 5.75\% in K2. The two cocoa clones treated with endophytic fungi, i.e., Paecilomyces sp. EP1, Paecilomyces sp. EP2 and Paecilomyces sp. EP1 + Trichoderma sp.) did not show symptoms of VSD until 20 weeks after planting.
\end{abstract}

Keywords: cocoa, clone, endophyte fungi, Ceratobasidium theobromae, disease incidence, VSD

ABSTRAK

Peran Klon Kakao dan Cendawan Endofit dalam Mengendalikan Penyakit VSD pada Tanaman Kakao di Lapang

Cendawan Ceratobasidium theobromae adalah penyebab penyakit vascular streak dieback (VSD) pada tanaman kakao. Penyakit VSD dapat menyebabkan kematian pada klon rentan lebih dari 59\%. Penggunaan klon kakao yang tahan dan cendawan endofit dapat menjadi alternatif pengendalian penyakit VSD. Tujuan penelitian adalah mengevaluasi kemampuan klon kakao dan cendawan endofit dalam mengendalikan penyakit VSD di lapangan. Desain percobaan yang digunakan adalah rancangan acak kelompok dengan pola faktorial. Faktor pertama adalah klon kakao, yang terdiri dari Klon 45 (K1) dan 25 (K2), dan faktor kedua adalah beberapa jenis cendawan endofit. Hasil penelitian menunjukkan adanya interaksi antara klon kakao dengan isolat cendawan endofit terhadap pertambahan tinggi dan jumlah daun kakao. Kedua klon kakao yang diuji dapat terinfeksi secara alami oleh $C$. theobromae tanpa cendawan endofit, dengan kejadian penyakit VSD 5, 21\% pada K1 dan 5,75\% pada K2. Kedua klon kakao yang diberi cendawan endofit (Paecilomyces sp. EP1, Paecilomyces sp. EP2 and Paecilomyces sp. EP1 + Trichoderma sp.) tidak menunjukkan gejala VSD sampai masa 20 MST.

Kata Kunci: kakao, klon, cendawan endofit, Ceratobasidium theobromae, kejadian penyakit, VSD

\section{PENDAHULUAN}

Kakao (Theobromae cacao L.) adalah tanaman perkebunan yang memiliki nilai ekonomi yang tinggi dan menjadi salah satu komoditas penting dalam perdagangan internasional. Kakao merupakan komoditi yang memiliki nilai ekonomi tinggi sehingga beberapa negara berupaya meningkatkan produksi kakao untuk mensuplai kebutuhan kakao dunia seperti Pantai Gading yang mensuplai 39,8\%, Ghana 19,6\% dan Indonesia 8,1\% (ICCO, 2017). Data kakao Indonesia yang diusahakan oleh perkebunan rakyat Tahun 2016 tercatat seluas 1.678 .638 ha, kemudian mengalami penurunan sekitar 3,73\% pada Tahun 2017 menjadi seluas 1.615.955 ha. Pada Tahun 2018 luas areal kakao perkebunan rakyat juga mengalami penurunan menjadi 1.584 .133 ha atau turun sebesar 1,97\% dari Tahun 2017 (Direktorat Jenderal Perkebunan, 2019).

Provinsi Sulawesi Tenggara ditinjau dari luas pertanaman kakao merupakan daerah penghasil kakao terbesar kedua di Indonesia setelah Sulawesi Selatan. Luas perkebunan kakao di Sulawesi Tenggara didominasi oleh perkebunan rakyat seluas 255.350 ha, dengan produksi kakao tahun 2017 sebesar 92.831 ton, hasil tersebut lebih rendah dibandingkan dengan produksi kakao pada tahun 2016 yang mencapai 101.030 ton (BPS, 2018).

Salah satu penyakit yang menyebabkan produktivitas kakao menurun yaitu Vascular Streak Dieback (VSD) yang disebabkan oleh cendawan Ceratobasidium theobromae (Taufik et al., 2019a). Penyakit VSD sebagai penyakit mati pucuk pada tanaman kakao yang tersebar di Sulawesi Tenggara, Sulawesi Selatan, Kalimantan Timur, dan Halmahera. Di Sulawesi Tengah, dari total 224.113 ha kebun kakao, sekitar $75 \%$ terserang penyakit VSD. Dinas Perkebunan Sulawesi Selatan menyebutkan bahwa penyakit VSD menyerang 1,3 juta hektare kakao di Indonesia yang membuat produksi nasional kakao turun sampai 40\% (PPPT, 2019). 
Pengendalian yang umum dilakukan oleh petani adalah secara kimiawi menggunakan fungisida sintetik, namun teknik pengendalian tersebut belum efektif mengendalikan patogen yang ada di dalam jaringan tanaman seperti penyakit VSD. Salah satu solusi yang dapat digunakan adalah cendawan endofit yang hidup di dalam jaringan tanaman kakaocendawan endofit. Cendawan endofit hidup di dalam jaringan tanaman tetapi tidak menyebabkan gejala penyakit dan memiliki aktivitas melawan infeksi patogen di jaringan tanaman, serta menjadi salah satu alternatif pengendalian yang tepat guna dan ramah lingkungan (Clay, 1992).

Cendawan endofit yang berasal dari tangkai daun kakao yang diisolasi dari beberapa lokasi tanaman kakao di Sulawesi Tenggara, berhasil diidentifikasi tiga genus cendawan endofit, Paecilomyces sp., Cladosporium sp. dan Nigrospora sp. mampu meningkatkan perkecambahan benih kakao 90-100\%, sehingga diduga memiliki potensi untuk mengendalikan penyakit VSD (Assad et al., 2017). Cendawan endofit tersebut dilaporkan mampu menghambat perkembangan patogen melalui proses mikroparasi, antibiosis dan kompetisi (Ismail \& Tenrirawe, 2011).

Cendawan endofit berpotensi sebagai agens biokontrol yang dapat diisolasi dari tanaman dan mampu hidup dan membentuk koloni dalam jaringan tanaman tanpa menimbulkan gejala sakit pada inangnya. Hakkar dkk. (2014) melaporkan bahwa buah kakao yang diberi cendawan endofit Trichoderma asperellum dengan konsentrasi 2 dan $4 \mathrm{~g}$ L-1 tidak memperlihatkan gejala busuk buah kakao setelah diinkubasi di laboratorium 1 minggu, sedangkan pada kontrol hampir seluruh permukaan buahnya membusuk. Cendawan endofit tersebut dapat direisolasi dari jaringan buah 12 minggu setelah penyemprotan.

Aziz dkk. (2014) juga melaporkan bahwa T. asperellum yang diaplikasikan pada benih kakao dengan konsentrasi spora $104 \mathrm{~mL}-1,105 \mathrm{~mL}-1$ dan $106 \mathrm{~mL}-1$. Intensitas penyakit dengan perlakuan konsentrasi spora tersebut berturut-turut adalah $39.0 \%, 23.6 \%$, dan $21.8 \%$ untuk isolat ARBT-1 dan $30.6 \%$, 25.7\%, dan $30.8 \%$ untuk isolat ART-4, sedangkan pada perlakuan kontrol mencapai $90.3 \%$ pada 21 hari setelah inokulasi dengan patogen.

Perbedaan ketahanan kakao terhadap penyakit VSD berbeda-beda bergantung klon yang digunakan, dilaporkan bahwa kakao klon Sul 1 dan PA 191 lebih tahan dibandingkan dengan klon BL 703 dan GC 29 terhadap penyakit VSD (Nono et al., 2017). Sementara penggunaan agens hayati atau mikroba menguntungkan pada klon kakao terhadap kejadian penyakit VSD dapat mengurangi kejadian penyakit VSD lebih dari 33\% pada klon Sulawesi 1 dan klon Sulawesi 7 (Wahab et al., 2016). Berdasarkan latar belakang tersebut maka tujuan penelitian adalah mengevaluasi kombinasi klon kakao (T. cacao L.) dengan cendawan endofit untuk mengendalikan penyakit VSD pada tanaman kakao di lapang.

\section{BAHAN DAN METODE}

Penelitian dilaksanakan di Desa Wolasi, Kecamatan Wolasi, Kabupaten Konawe Selatan. Lahan yang digunakan adalah kebun kakao milik petani yang telah diidentifikasi berdasarkan gejala penyakit VSD sebelumnya, sehingga diharapkan terjadi infeksi alamiah ke tanaman kakao uji. Laboratorium Proteksi Tanaman Unit Fitopatologi Fakultas Pertanian Universitas Halu Oleo, Kendari. Penelitian ini dimulai pada bulan Oktober 2019 sampai Maret 2020.

\section{Rancangan Penelitian}

Metode yang digunakan adalah metode Rancangan Acak Kelompok dengan pola faktorial yang terdiri dari dua faktor, faktor pertama adalah klon kakao yaitu K1 = Klon 45 dan K2 = Klon 25 . Faktor kedua adalah cendawan endofit yaitu :

$$
\begin{aligned}
\mathrm{C} 0= & \text { Kontrol } \\
\mathrm{C} 1= & \text { Aplikasi fungisida Dithane M-45 } 80 \mathrm{WP} \\
& \text { dengan bahan aktif Mankozeb } 80 \% \\
\mathrm{C} 2= & \text { Aplikasi cendawan endofit Paecilomyces } \\
& \text { sp. Isolat EP1 } \\
\mathrm{C} 3= & \text { Aplikasi cendawan endofit Paecilomyces } \\
& \text { sp. Isolat EP2 } \\
\mathrm{C} 4= & \text { Aplikasi cendawan endofit Trichoderma } \\
& \text { sp. } \\
\mathrm{C} 5= & \text { Aplikasi cendawan endofit Paecilomyces } \\
& \text { sp. Isolat EP1 }+ \text { Paecilomyces sp. Isolat } \\
& \text { EP2 } \\
\mathrm{C} 6= & \text { Aplikasi cendawan endofit Paecilomyces } \\
& \text { sp. Isolat EP1 + cendawan endofit } \\
& \text { Trichoderma sp. } \\
\mathrm{C} 7= & \text { Aplikasi cendawan endofit Paecilomyces } \\
& \text { sp. Isolat EP2 + cendawan endofit } \\
& \text { Trichoderma sp. }
\end{aligned}
$$

Total 16 unit kombinasi perlakuan, masingmasing kombinasi perlakuan dikelompokkan sebanyak 4 kelompok, sehingga terdapat 64 unit tanaman.

\section{Persiapan Lahan}

Lahan diolah dan dibuat lubang tanam berukuran $50 \times 50 \times 50 \mathrm{~cm}$ dengan jarak tanan $3 \times$ 3 m. Tanaman kakao berumur 3 bulan siap dipindahkan ke lapang. Sebelumnya tanaman kakao diperbanyak dengan biji yang diperoleh dari penangkar kakao yang telah ditunjuk oleh Dinas Perkebunan Sulawesi Tenggara.

\section{Penumbuhan dan Aplikasi Cendawan Endopfit pada Benih Kakao}

Isolat cendawan endofit tersebut ditumbuhkan pada media PDA, setelah berumur 7 hari dibuat dalam suspensi dengan cara: sebanyak $10 \mathrm{~mL}$ aquades steril 
dimasukkan ke dalam cawan petri berdiameter $9 \mathrm{~cm}$ yang telah ditumbuhkan biakan cendawan endofit dan diratakan dengan bantuan spatula. Suspensi tersebut kemudian dimasukkan ke dalam tabung erlenmeyer dan ditambahkan aquades steril $100 \mathrm{~m}$. Waktu aplikasi cendawan endofit dilakukan dua kali yaitu pada saat biji kakao ditanam di polibag dan saat pindah tanam ke lapang. Biji kakao disemprot dengan suspensi cendawan endofit sampai seluruh permukaan biji kakao telah basah oleh suspensi cendawan endofit. Sementara aplikasi cendawan endofit tahap kedua dilakukan pada daun kakao yang telah berumur 3 bulan setelah tanam. Sebanyak dua ujung daun kakao sepanjang 2-3 cm dicelupkan ke dalam suspensi cendawan endofit.

\section{Penanaman dan Pemeliharaan Tanaman Kakao}

Benih dipidah tanam ke lubang tanam yang telah disiapkan sebelumnya. Lubang tanam diisi dengan tanah top soil dan pupuk kandang sapi dengan perbandingan $2: 1 \mathrm{v} / \mathrm{v}$. Saat benih dipindahtanam diberi suspensi cendawan endofit sesuai perlakuan, Aplikasi cendawan endofit diulangi setelah tanaman kakao berumur satu bulan setelah pindah tanam. Dosis pupuk NPK yang digunakan adalah $400 \mathrm{~g}$ per pohon yang diberikan dua kali, $100 \mathrm{~g}$ pertama diberikan 1 minggu sebelum tanam di lapang dengan cara dicampur dengan tanah top soil dan pupuk kandang sapi. Sisanya diberikan setelah tanaman kakao berumur satu bulan setelah benih kakao ditanam di lapang. Pemeliharaan tanaman meliputi penyiraman, penyiangan dan pengendalian hama secara mekanis.

\section{Variabel yang Diamati}

Variabel pengamatan adalah:

1. Pertambahan tinggi tanaman $(\mathrm{cm})$, diukur mulai dari permukaan tanah sampai titik tumbuh. Pengambilan data tinggi tanaman dilakukan pada pengamatan 4, 12, dan 20 minggu setelah tanam (MST). Pertambahan tinggi tanaman dihitung dengan cara tinggi tanaman saat pengamatan dikurangi tinggi tanaman saat pindah tanam.

2. Pertambahan Jumlah daun (helai), dihitung ketika daun terbuka sempurna yang terbentuk pada tanaman. Jumlah daun dihitung pada 4, 12, dan 20 MST. Pertambahan jumlah daun tanaman dihitung dengan cara jumlah daun tanaman saat pengamatan dikurangi jumlah daun tanaman saat pindah tanam.

3. Tingkat kejadian penyakit dihitung pada 8, 12, 16 dan 20 MST dengan mengamati adanya gejala khas tiga noktah pada tankai daun kakao sampel. Untuk menghitung tingkat kejadian penyakit VSD menggunakan rumus sebagai berikut.

$$
K P=\frac{n}{N} \times 100 \%
$$

Keterangan: KP : Kejadian penyakit (\%)

$\mathrm{n}$ : Jumlah daun yang bergejala

$\mathrm{N}$ : Total jumlah daun yang diamati

\section{Analisis Data}

Data pertambahan tinggi tanaman dan jumlah daun yang diperoleh dianalisis dengan analisis sidik ragam (Anova) dan apabila perlakuan berpengaruh nyata berdasarkan uji $\mathrm{F}$, maka dilakukan uji lanjut dengan membandingkan nilai rataan perlakuan dengan Duncan Multiple Range Test (DMRT) pada $\alpha=0,05$. Untuk kejadian penyakit digunakan tabulasi sederhana.

\section{HASIL DAN PEMBAHASAN}

\section{Tinggi Tanaman Kakao (cm)}

Rata-rata tinggi tanaman tertinggi 4 MST terlihat pada kombinasi perlakuan klon dengan cendawan endofit diperoleh pada perlakuan klon 45 dengan cendawan endofit Paecilomyces sp. plus Trichoderma sp. (K1C7) sebesar 19,75 cm yang berbeda tidak nyata dengan kombinasi klon 25 dengan perlakuan cendawan endofit Paecilomyces sp. plus Trichoderma sp. (K2C7) sebesar 9,75 cm. Sementara kombinasi perlakuan yang terendah terlihat pada kombinasi $\mathrm{K} 2 \mathrm{C} 0$ sebesar $4,75 \mathrm{~cm}$ yang berbeda nyata dengan kombinasi K1C0 sebesar 8,25 cm (Tabel 1).

Rata-rata tinggi tanaman tertinggi 12 MST terlihat pada kombinasi perlakuan klon dengan cendawan endofit diperoleh pada perlakuan klon 45 dengan cendawan endofit Paecilomyces sp. plus Trichoderma sp. (K1C7) sebesar 27,00 cm yang berbeda nyata dengan kombinasi klon 25 dengan perlakuan cendawan endofit Paecilomyces sp. plus Trichoderma sp. (K2C7) sebesar 18,00 cm. Sementara kombinasi perlakuan yang terendah terlihat pada kombinasi K2C0 sebesar 10,00 cm yang berbeda tidak nyata dengan kombinasi K1C0 sebesar10,75 cm (Tabel 2).

Rata-rata tinggi tanaman tertinggi 20 MST terlihat pada kombinasi perlakuan klon dengan cendawan endofit diperoleh pada perlakuan klon 25 dengan cendawan endofit Paecilomyces sp. Isolat EP1 plus Paecilomyces sp. Isolat EP2 (K2C5) sebesar $40,75 \mathrm{~cm}$ yang berbeda nyata dengan kombinasi klon 45 dengan perlakuan cendawan endofit Paecilomyces sp. Isolat EP1 plus Paecilomyces sp. Isolat EP2 (K1C5) sebesar 28,75 cm. Sementara kombinasi perlakuan yang terendah terlihat pada kombinasi K2C0 sebesar $16,50 \mathrm{~cm}$ yang berbeda tidak nyata dengan kombinasi K1C0 sebesar 17,75 cm (Tabel 3). 
Tabel 1. Rerata Pertambahan Tinggi Tanaman Kakao $(\mathrm{cm})$ yang Diberi Perlakuan Kombinasi Cendawan Endofit pada Klon yang Berbeda pada Pengamatan 4 MST

\begin{tabular}{|c|c|c|c|}
\hline \multirow{2}{*}{ Cendawan Endofit } & \multicolumn{2}{|c|}{ Klon Kakao } & \multirow{2}{*}{ DMRT } \\
\hline & Klon 45 (K1) & Klon 25 (K2) & \\
\hline \multirow[t]{2}{*}{ Kontrol } & $8,25 \mathrm{r}$ & $4,75 \mathrm{q}$ & 2,70 \\
\hline & $\mathrm{a}$ & $\mathrm{b}$ & 2,84 \\
\hline \multirow[t]{2}{*}{ Fungisida } & $10,25 \mathrm{qr}$ & $8,50 \mathrm{p}$ & 2,93 \\
\hline & $\mathrm{a}$ & $\mathrm{a}$ & 2,99 \\
\hline \multirow[t]{2}{*}{ Paecilomyces sp.EP1 } & $13,00 \mathrm{q}$ & $10,75 \mathrm{p}$ & 3,05 \\
\hline & $\mathrm{a}$ & $\mathrm{a}$ & 3,09 \\
\hline \multirow[t]{2}{*}{ Paecilomyces sp.EP2 } & $10,75 \mathrm{qr}$ & $10,00 \mathrm{p}$ & 3,12 \\
\hline & $\mathrm{a}$ & a & \\
\hline \multirow[t]{2}{*}{ Trichoderma $\mathrm{sp}$} & $12,25 \mathrm{q}$ & $8,75 \mathrm{p}$ & \\
\hline & a & $\mathrm{b}$ & \\
\hline \multirow[t]{2}{*}{$\begin{array}{l}\text { Paecilomyces sp. EP1 + } \\
\text { Paecilomyces } \mathrm{sp} . \mathrm{EP} 2\end{array}$} & $9,25 \mathrm{r}$ & $8,00 \mathrm{p}$ & \\
\hline & $\mathrm{a}$ & $\mathrm{a}$ & \\
\hline \multirow[t]{2}{*}{$\begin{array}{l}\text { Paecilomyces sp.EP1 + } \\
\text { Trichoderma } \mathrm{sp}\end{array}$} & $9,00 \mathrm{r}$ & $7,75 \mathrm{p}$ & \\
\hline & $\mathrm{a}$ & $\mathrm{a}$ & \\
\hline \multirow[t]{2}{*}{$\begin{array}{l}\text { Paecilomyces } \mathrm{sp} . \mathrm{EP} 2+ \\
\text { Trichoderma } \mathrm{sp},\end{array}$} & $19,75 \mathrm{p}$ & $9,75 \mathrm{p}$ & \\
\hline & $\mathrm{a}$ & $\mathrm{b}$ & \\
\hline
\end{tabular}

Keterangan: Angka-angka yang diikuti oleh huruf sama pada kolom (pqr) dan baris (ab) yang sama tidak berbeda nyata pada taraf kepercayaan $95 \%$.

Tabel 2 Rerata Pertambahan Tinggi Tanaman Kakao (cm) yang Diberi Perlakuan Kombinasi Cendawan Endofit pada Klon yang Berbeda pada Pengamatan 12 MST

\begin{tabular}{|c|c|c|c|c|c|}
\hline \multirow{2}{*}{ Cendawan Endofit } & \multicolumn{4}{|c|}{ Klon Kakao } & \multirow{2}{*}{ DMRT } \\
\hline & \multicolumn{2}{|c|}{ Klon 45 (K1) } & \multicolumn{2}{|c|}{ Klon 25 (K2) } & \\
\hline \multirow[t]{2}{*}{ Kontrol } & 10,75 & $\mathrm{t}$ & 10,00 & $\mathrm{q}$ & 4,65 \\
\hline & $\mathrm{a}$ & & $\mathrm{a}$ & & 4,90 \\
\hline \multirow[t]{2}{*}{ Fungisida } & 16,50 & st & 18,25 & $\mathrm{p}$ & 5,06 \\
\hline & $\mathrm{a}$ & & $\mathrm{a}$ & & 5,16 \\
\hline \multirow[t]{2}{*}{ Paecilomyces sp.EP1 } & 20,75 & $\mathrm{qr}$ & 19,75 & $\mathrm{p}$ & 5,26 \\
\hline & $\mathrm{a}$ & & $\mathrm{a}$ & & 5,33 \\
\hline \multirow[t]{2}{*}{ Paecilomyces sp.EP2 } & 23,25 & $\mathrm{pq}$ & 22,00 & $\mathrm{p}$ & 5,39 \\
\hline & $\mathrm{a}$ & & $\mathrm{a}$ & & \\
\hline \multirow[t]{2}{*}{ Trichoderma sp } & 24,75 & $\mathrm{pq}$ & 18,75 & $\mathrm{p}$ & \\
\hline & $\mathrm{a}$ & & $\mathrm{b}$ & & \\
\hline \multirow{2}{*}{$\begin{array}{l}\text { Paecilomyces sp. EP1 + } \\
\text { Paecilomyces sp. EP2 }\end{array}$} & 18,00 & $\mathrm{r}$ & 23,25 & $\mathrm{p}$ & \\
\hline & $\mathrm{b}$ & & $\mathrm{a}$ & & \\
\hline \multirow{2}{*}{$\begin{array}{l}\text { Paecilomyces sp.EP1 + } \\
\text { Trichoderma } \mathrm{sp}\end{array}$} & 18,00 & rs & 13,00 & $q$ & \\
\hline & $\mathrm{a}$ & & $\mathrm{b}$ & & \\
\hline \multirow{2}{*}{$\begin{array}{l}\text { Paecilomyces sp. EP2 + } \\
\text { Trichoderma } \mathrm{sp},\end{array}$} & 27,00 & $\mathrm{p}$ & 18,00 & $\mathrm{p}$ & \\
\hline & $\mathrm{a}$ & & $\mathrm{b}$ & & \\
\hline
\end{tabular}

Keterangan: Angka-angka yang diikuti oleh huruf sama pada kolom (pqr) dan baris (ab) yang sama tidak berbeda nyata pada taraf kepercayaan $95 \%$. 
Tabel 3 Rerata Pertambahan Tinggi Tanaman Kakao (cm) yang Diberi Perlakuan Kombinasi Cendawan Endofit pada Klon yang Berbeda pada Pengamatan 20 MST

\begin{tabular}{|c|c|c|c|c|c|}
\hline \multirow{2}{*}{ Cendawan Endofit } & \multicolumn{4}{|c|}{ Klon Kakao } & \multirow{2}{*}{ DMRT } \\
\hline & \multicolumn{2}{|c|}{ Klon 45 (K1) } & \multicolumn{2}{|c|}{ Klon 25 (K2) } & \\
\hline \multirow[t]{2}{*}{ Kontrol } & 17,75 & $\mathrm{t}$ & 16,50 & $\mathrm{t}$ & 4,75 \\
\hline & $\mathrm{a}$ & & $\mathrm{a}$ & & 5,00 \\
\hline \multirow[t]{2}{*}{ Fungisida } & 20,50 & s & 27,50 & s & 5,17 \\
\hline & $\mathrm{a}$ & & $\mathrm{b}$ & & 5,27 \\
\hline \multirow[t]{2}{*}{ Paecilomyces sp.EP1 } & 28,25 & $\mathrm{q}$ & 28,75 & $\mathrm{~s}$ & 5,37 \\
\hline & $\mathrm{a}$ & & $\mathrm{b}$ & & 5,44 \\
\hline \multirow[t]{2}{*}{ Paecilomyces sp.EP2 } & 26,75 & $\mathrm{q}$ & 32,25 & $\mathrm{r}$ & 5,50 \\
\hline & $\mathrm{b}$ & & $\mathrm{a}$ & & \\
\hline \multirow[t]{2}{*}{ Trichoderma sp } & 32,25 & $\mathrm{p}$ & 33,75 & $\mathrm{qr}$ & \\
\hline & $\mathrm{a}$ & & $\mathrm{a}$ & & \\
\hline \multirow{2}{*}{$\begin{array}{l}\text { Paecilomyces sp. EP1 + } \\
\text { Paecilomyces } \mathrm{sp} . \mathrm{EP} 2\end{array}$} & 28,75 & $q$ & 40,75 & $\mathrm{p}$ & \\
\hline & $\mathrm{b}$ & & $\mathrm{a}$ & & \\
\hline \multirow{2}{*}{$\begin{array}{l}\text { Paecilomyces } \mathrm{sp} . \mathrm{EP} 1+ \\
\text { Trichoderma } \mathrm{sp}\end{array}$} & 23,50 & $\mathrm{r}$ & 35,75 & $\mathrm{q}$ & \\
\hline & $\mathrm{b}$ & & $\mathrm{a}$ & & \\
\hline \multirow{2}{*}{$\begin{array}{l}\text { Paecilomyces sp. EP } 2+ \\
\text { Trichoderma } \mathrm{sp},\end{array}$} & 28,75 & $\mathrm{pq}$ & 27,50 & $\mathrm{~s}$ & \\
\hline & $\mathrm{a}$ & & $b$ & & \\
\hline
\end{tabular}

Keterangan: Angka-angka yang diikuti oleh huruf sama pada kolom (pqr) dan baris (ab) yang sama tidak berbeda nyata pada taraf kepercayaan $95 \%$.

\section{Jumlah Daun Kakao (Helai)}

Rata-rata jumlah daun terbanyak 4 MST terlihat pada kombinasi perlakuan klon dengan cendawan endofit diperoleh pada perlakuan klon 45 dengan cendawan endofit Trichoderma sp. (K1C4) sebanyak 15,50 helai yang berbeda tidak nyata dengan kombinasi klon 25 dengan perlakuan cendawan endofit Trichoderma sp. (K2C4) sebanyak 13,00 helai. Rata-rata jumlah daun terendah terdapat pada kombinasi perlakuan $\mathrm{K} 2 \mathrm{C} 0$ sebanyak 9,50 helai (Tabel 4).

Tabel 4. Rerata Pertambahan Jumlah Daun Kakao (Helai) yang Diberi Perlakuan Kombinasi Cendawan Endofit pada Klon yang Berbeda pada Pengamatan 4 MST

\begin{tabular}{|c|c|c|c|c|c|}
\hline \multirow{2}{*}{ Cendawan Endofit } & \multicolumn{4}{|c|}{ Klon Kakao } & \multirow{2}{*}{ DMRT } \\
\hline & \multicolumn{2}{|c|}{ Klon $45(\mathrm{~K} 1)$} & \multicolumn{2}{|c|}{ Klon 25 (K2) } & \\
\hline \multirow[t]{2}{*}{ Kontrol } & 11,25 & $q$ & 9,50 & $q$ & 2,86 \\
\hline & $\mathrm{a}$ & & $\mathrm{a}$ & & 3,01 \\
\hline \multirow[t]{2}{*}{ Fungisida } & 11,50 & $q$ & 13,25 & $\mathrm{p}$ & 3,11 \\
\hline & $\mathrm{a}$ & & $\mathrm{a}$ & & 3,17 \\
\hline \multirow[t]{2}{*}{ Paecilomyces sp.EP1 } & 11,75 & $\mathrm{q}$ & 14,25 & $\mathrm{p}$ & 3,23 \\
\hline & $\mathrm{a}$ & & $\mathrm{a}$ & & 3,27 \\
\hline \multirow[t]{2}{*}{ Paecilomyces sp.EP2 } & 12,25 & $\mathrm{q}$ & 14,25 & $\mathrm{p}$ & 3,31 \\
\hline & $\mathrm{a}$ & & $\mathrm{a}$ & & \\
\hline Trichoderma $\mathrm{sp}$ & $\begin{array}{c}15,50 \\
\mathrm{a}\end{array}$ & $\mathrm{p}$ & $\begin{array}{c}13,00 \\
\mathrm{a}\end{array}$ & $\mathrm{p}$ & \\
\hline \multirow[t]{2}{*}{$\begin{array}{l}\text { Paecilomyces sp. EP1 + } \\
\text { Paecilomyces } \text { sp. EP2 }\end{array}$} & 12,25 & $\mathrm{q}$ & 12,50 & $\mathrm{p}$ & \\
\hline & $\mathrm{a}$ & & $\mathrm{a}$ & & \\
\hline \multirow[t]{2}{*}{$\begin{array}{l}\text { Paecilomyces sp.EP1 + } \\
\text { Trichoderma } \mathrm{sp}\end{array}$} & 15,25 & $\mathrm{pq}$ & 15,25 & $\mathrm{p}$ & \\
\hline & $\mathrm{a}$ & & $\mathrm{a}$ & & \\
\hline \multirow[t]{2}{*}{$\begin{array}{l}\text { Paecilomyces } \mathrm{sp} . \mathrm{EP} 2+ \\
\text { Trichoderma } \mathrm{sp},\end{array}$} & 15,00 & $\mathrm{pq}$ & 14,50 & $\mathrm{p}$ & \\
\hline & $\mathrm{a}$ & & $\mathrm{a}$ & & \\
\hline
\end{tabular}

Keterangan: Angka-angka yang diikuti oleh huruf sama pada kolom (pqr) dan baris (ab) yang sama tidak berbeda nyata pada taraf kepercayaan $95 \%$. 
Rata-rata jumlah daun terbanyak terlihat pada kombinasi perlakuan klon dengan cendawan endofit diperoleh pada perlakuan klon 45 dengan cendawan endofit Trichoderma sp. (K1C4) sebanyak 27,00 helai yang berbeda nyata dengan kombinasi klon 25 dengan perlakuan cendawan endofit
Trichoderma sp. (K2C4) sebanyak 19,50 helai. Sementara kombinasi perlakuan yang terendah terlihat pada kombinasi K1C0 sebanyak 14,25 helai yang berbeda tidak nyata dengan kombinasi K2C0 sebanyak 14,75 helai (Tabel 5).

Tabel 5 Rerata Pertambahan Jumlah Daun Kakao (Helai) yang Diberi Perlakuan Kombinasi Cendawan Endofit pada Klon yang Berbeda pada Pengamatan 12 MST

\begin{tabular}{|c|c|c|c|c|c|}
\hline \multirow{2}{*}{ Cendawan Endofit } & \multicolumn{4}{|c|}{ Klon } & \multirow{2}{*}{ DMRT } \\
\hline & \multicolumn{2}{|c|}{ Klon 45 (K1) } & \multicolumn{2}{|c|}{ Klon $25(\mathrm{~K} 2)$} & \\
\hline \multirow[t]{2}{*}{ Kontrol } & 14,25 & $\mathrm{r}$ & 14,75 & $q$ & 3,69 \\
\hline & $\mathrm{a}$ & & $\mathrm{a}$ & & 3,88 \\
\hline \multirow[t]{2}{*}{ Fungisida } & 15,25 & $\mathrm{r}$ & 18,50 & $q$ & 4,01 \\
\hline & $\mathrm{a}$ & & $\mathrm{a}$ & & 4,09 \\
\hline \multirow[t]{2}{*}{ Paecilomyces sp.EP1 } & 15,25 & $\mathrm{r}$ & 19,00 & $\mathrm{pq}$ & 4,17 \\
\hline & b & & $\mathrm{a}$ & & 4,22 \\
\hline \multirow[t]{2}{*}{ Paecilomyces sp.EP2 } & 18,25 & $\mathrm{r}$ & 18,00 & $\mathrm{pq}$ & 4,27 \\
\hline & $\mathrm{a}$ & & $\mathrm{a}$ & & \\
\hline \multirow[t]{2}{*}{ Trichoderma $\mathrm{sp}$} & 27,00 & $\mathrm{p}$ & 19,50 & $\mathrm{pq}$ & \\
\hline & $\mathrm{a}$ & & $\mathrm{b}$ & & \\
\hline \multirow[t]{2}{*}{$\begin{array}{l}\text { Paecilomyces } \mathrm{sp} . \mathrm{EP} 1+ \\
\text { Paecilomyces } \mathrm{sp} . \mathrm{EP} 2\end{array}$} & 20,75 & $\mathrm{qr}$ & 18,00 & $\mathrm{pq}$ & \\
\hline & $\mathrm{a}$ & & $\mathrm{a}$ & & \\
\hline \multirow[t]{2}{*}{$\begin{array}{l}\text { Paecilomyces sp.EP1 + } \\
\text { Trichoderma } \mathrm{sp}\end{array}$} & 19,25 & $\mathrm{qr}$ & 21,25 & $\mathrm{p}$ & \\
\hline & $\mathrm{a}$ & & $\mathrm{a}$ & & \\
\hline \multirow[t]{2}{*}{$\begin{array}{l}\text { Paecilomyces sp. EP2 + } \\
\text { Trichoderma } \mathrm{sp},\end{array}$} & 22,00 & $\mathrm{q}$ & 21,00 & $\mathrm{p}$ & \\
\hline & $\mathrm{a}$ & & $\mathrm{a}$ & & \\
\hline
\end{tabular}

Keterangan: Angka-angka yang diikuti oleh huruf sama pada kolom (pqr) dan baris (ab) yang sama tidak berbeda nyata pada taraf kepercayaan $95 \%$.

Rata-rata jumlah daun terbanyak terlihat pada kombinasi perlakuan klon dengan cendawan endofit diperoleh pada perlakuan klon 45 dengan cendawan endofit Trichoderma sp. (K1C4) sebanyak 50, 75 helai yang berbeda nyata dengan kombinasi klon 25 dengan perlakuan cendawa nendofit Trichoderma sp. (K2C4) sebanyak 35,50 helai. Sementara kombinasi perlakuan yang terendah terlihat pada kombinasi K2C0 sebanyak 21,50 helai yang berbeda tidak nyata dengan kombinasi K1C0 sebanyak 25 helai (Tabel 6).

Tabel 6 Rerata Pertambahan Jumlah Daun Kakao (Helai) yang Diberi Perlakuan Kombinasi Cendawan Endofit pada Klon yang Berbeda pada Pengamatan 20 MST

\begin{tabular}{|c|c|c|c|c|c|}
\hline \multirow{2}{*}{ Cendawan Endofit } & \multicolumn{4}{|c|}{ Klon } & \multirow{2}{*}{ UJBD } \\
\hline & \multicolumn{2}{|c|}{ Klon $45(\mathrm{~K} 1)$} & \multicolumn{2}{|c|}{ Klon 25 (K2) } & \\
\hline \multirow{2}{*}{ Kontrol } & 25,00 & s & 21,50 & $\mathrm{r}$ & 3,97 \\
\hline & a & & $\mathrm{a}$ & & 4,18 \\
\hline \multirow[t]{2}{*}{ Fungisida } & 26,25 & $\mathrm{~s}$ & 25,00 & $\mathrm{r}$ & 4,32 \\
\hline & $\mathrm{a}$ & & $\mathrm{a}$ & & 4,40 \\
\hline \multirow[t]{2}{*}{ Paecilomyces sp.EP1 } & 33,75 & $\mathrm{r}$ & 31,75 & $q$ & 4,49 \\
\hline & $\mathrm{a}$ & & $\mathrm{a}$ & & 4,54 \\
\hline \multirow[t]{2}{*}{ Paecilomyces sp.EP2 } & 36,75 & $\mathrm{qr}$ & 29,50 & $\mathrm{qr}$ & 4,60 \\
\hline & $\mathrm{a}$ & & $\mathrm{b}$ & & \\
\hline Trichoderma $\mathrm{sp}$ & 50,75 & $\mathrm{p}$ & 35,50 & $\mathrm{pq}$ & \\
\hline \multirow[t]{2}{*}{$\begin{array}{l}\text { Paecilomyces sp. EP1 + } \\
\text { Paecilomyces } \mathrm{sp} . \mathrm{EP} 2\end{array}$} & 36,75 & $\mathrm{qr}$ & 28,25 & qr & \\
\hline & $\mathrm{a}$ & & b & & \\
\hline \multirow[t]{2}{*}{$\begin{array}{l}\text { Paecilomyces } \mathrm{sp} . \mathrm{EP} 1+ \\
\text { Trichoderma } \mathrm{sp}\end{array}$} & 34,50 & $\mathrm{r}$ & 37,50 & $\mathrm{p}$ & \\
\hline & $\mathrm{b}$ & & $\mathrm{a}$ & & \\
\hline \multirow[t]{2}{*}{$\begin{array}{l}\text { Paecilomyces } \mathrm{sp} . \mathrm{EP} 2+ \\
\text { Trichoderma } \mathrm{sp},\end{array}$} & 42,00 & q & 34,00 & $\mathrm{pq}$ & \\
\hline & $\mathrm{a}$ & & b & & \\
\hline
\end{tabular}

Keterangan: Angka-angka yang diikuti oleh huruf sama pada kolom (pqr) dan baris (ab) yang sama tidak berbeda nyata pada taraf kepercayaan $95 \%$. 


\section{Kejadian Penyakit VSD}

Hasil rerata kejadian penyakit VSD berdasarka gejala tig aniktah pada tangkai daun kako pada pengamatan $8,12,16$ dan 20 MST disajikan pada Tabel 7. Hasil rerata persentase kejadian penyakit VSD pada pengamatan 20 MST menunjukkan bahwa kejadian penyakit VSD pada perlakuan K2C0 ( klon 25 dan tanpa cendawan endofit hayati) presentase kejadian penyakit tertinggi $(5,75 \%)$ dibandingkan dengan perlakuan lainnya. Sementara kejadian penyakit VSD yang terendah terlihat pada perlakuan $\mathrm{K} 2 \mathrm{C} 7$.

Tabel 7 Rerata Persentase Kejadian Penyakit VSD (\%) pada Tanaman Kakao Sesuai Perlakuan

\begin{tabular}{|c|c|c|c|c|}
\hline \multirow{2}{*}{ Perlakuan } & \multicolumn{4}{|c|}{ Rerata Kejadian Penyakit pada umur...MST (\%) } \\
\hline & $8 \mathrm{MST}$ & $12 \mathrm{MST}$ & $16 \mathrm{MST}$ & $20 \mathrm{MST}$ \\
\hline $\mathrm{K} 1 \mathrm{C} 0$ & 0,00 & 0,00 & 2,08 & 5,21 \\
\hline $\mathrm{K} 1 \mathrm{C} 1$ & 0,00 & 0,00 & 0,00 & 2,88 \\
\hline $\mathrm{K} 1 \mathrm{C} 2$ & 0,00 & 0,00 & 0,00 & 0,00 \\
\hline $\mathrm{K} 1 \mathrm{C} 3$ & 0,00 & 0,00 & 0,00 & 0,00 \\
\hline $\mathrm{K} 1 \mathrm{C} 4$ & 0,00 & 0,00 & 0,00 & 0,52 \\
\hline $\mathrm{K} 1 \mathrm{C} 5$ & 3,85 & 3,75 & 2,68 & 1,92 \\
\hline K1C6 & 0,00 & 0,00 & 0,00 & 0,00 \\
\hline $\mathrm{K} 1 \mathrm{C} 7$ & 0,00 & 0,00 & 0,00 & 0,60 \\
\hline $\mathrm{K} 2 \mathrm{C} 0$ & 0,00 & 0,00 & 0,00 & 5,75 \\
\hline $\mathrm{K} 2 \mathrm{C} 1$ & 0,00 & 0,00 & 0,00 & 1,04 \\
\hline $\mathrm{K} 2 \mathrm{C} 2$ & 0,00 & 0,00 & 0,00 & 0,00 \\
\hline $\mathrm{K} 2 \mathrm{C} 3$ & 0,00 & 0,00 & 0,00 & 0,00 \\
\hline $\mathrm{K} 2 \mathrm{C} 4$ & 0,00 & 0,00 & 0,00 & 0,00 \\
\hline K2C5 & 0,00 & 0,00 & 0,00 & 0,00 \\
\hline K2C6 & 0,00 & 0,00 & 0,00 & 0,00 \\
\hline $\mathrm{K} 2 \mathrm{C} 7$ & 0,00 & 0,00 & 0,00 & 0,81 \\
\hline
\end{tabular}

Keterangan: $0=$ tidak ada kejadian penyakit penyakit Vascular Streak Dieback (VSD) pada tanaman kakao. C0 $=$ Kontrol, $\mathrm{C} 1=$ Fungisida, $\mathrm{C} 2=$ Paecilomyces sp.EP1, C3 = Paecilomyces sp.EP2, C4 = Trichoderma sp., C5 = Paecilomyces sp. EP1 + Paecilomyces sp. EP2., C6 = Paecilomyces sp.EP1 + Trichoderma sp., C7 = Paecilomyces sp. EP2 + Trichoderma sp, K1= Klon 45, K2 = Klon 25.

\section{PEMBAHASAN}

Pengendalian patogen yang hanya dapat hidup pada jaringan tanaman yang masih hidup dengan menggunakan cendawan endofit antagonis menjadi salah satu alternatif pengendalian penyakit VSD. Selama ini Petani menggunakan fungisida atau cara budidaya seperti pemangkasan. Aplikasi fungisida sistemik membutuhkan aplikasi yang berulang-ulang untuk meningkatkan keefektivitasnya. Metode pemangkasan bagian tanaman yang sakit juga belum efektif karena bagian jaringan tanaman yang sehat belum tentu steril dari hifa atau miselium patogen VSD. Penelitian ini menggunakan dua cara yaitu klon kakao dan cendawan endofit. Varietas/klon tahan memberikan kemudahan di dalam penggunaannya karena tidak diperlukan aplikasi yang berulang-ulang dibandingkan dengan fungisida, sedangkan cendawan endofit diharapkan mampu melawan infeksi patogen VSD yang mungkin melalui beberapa mekanisme seperti yang telah dilaporkan yaitu kompetisi ruang, parasitasi, antibiosis, induksi ketahanan, dan stimulasi pertumbuhan melalu zat pengatur tumbuh yang dihasilkannya.

Interaksi antara klon kakao dan CEL juga nampak pada respon pertumbuhan vegetatif-tinggi tanaman, khususnya pada kombinasi klon 25 yang diberi cendawan endofit Paecilomyces sp. EP1 + Paecilomyces sp. EP2 (C5) atau kombinasi C5K2 menghasilkan tinggi tanaman tertinggi yaitu $40,75 \mathrm{~cm}$ pada 20 MST atau pada akhir pengamatan. Diduga cendawan endofit yang digunakan mendorong tinggi tanaman kakao klon 25 dibandingkan dengan klon 45. Hasil penelitian Kurniawan dkk. (2017) menunjukkan bahwa pengaruh pemberian cendawan endofit asal tanaman kelapa sawit dapat meningkatkan pertumbuhan kelapa sawit pada tanah terinfeksi Ganoderma, dengan daun terluas pada perlakuan (Rhopalomyces sp. + Ganoderma sp.) yaitu 987,95 $\mathrm{cm}^{2}$ dan perlakuan Ra (Aspergillus. sp. + Ganoderma sp.) yaitu $905,36 \mathrm{~cm}^{2}$.

Hasil yang berbeda pada jumlah daun kakao klon 45 mempunyai jumlah daun rata-rata lebih banyak dibandingkan dengan klon 25 khususnya pada pengamatan 20 MST. Nampaknya terdapat interaksi pada kombinasi C4K1 yaitu aplikasi cendawan endofit Trichoderma sp. pada klon kakao 45 adalah kombinasi terbaik untuk mempromosi pertumbuhan jumlah daun tanaman. Hasil ini sama dengan penelitian yang dilakukan oleh Palad et al. (2016) bahwa benih tanamam kakao yang diaplikasikan Trichoderma asperellum sebanyak tiga kali menghasilkan jumlah daun 37 helai dan luas daun $1388,30 \mathrm{~cm}^{2}$ yang lebih tinggi dibandingkan dengan kontrol tanpa T. asperellum yaitu 24,56 dan 999,72 $\mathrm{cm}^{2}$ secara berturt-turut. Taufik et al. (2019b) menggunakan cendawan endofit juga mendorong pembentukan jumlah daun 22 helai sedangkan kontrol tanpa cendawan endofit jumlah daun 18 helai pada 8 
minggu setelah inokulasi. Diduga cendawan endofit menyebabkan multifikasi sel baik pemanjangan sel atau pembesaran mendorong pertumbuhan tinggi tanaman kakao, dan diferensiasi sel memicu formasi jaringan atau organ seperti jumlah daun. Kemampuan cendawan endofit dalam meningkatkan pertumbuhan tanaman bergantung pada kemampuannya memproduksi sejumlah zat pemacu tumbuh seperti giberelin dan auksin (Sriwichai et al., 2013).

Perbedaan respon masing-masing klon mungkin juga disebabkan oleh perbedaan genetik menyebabkan terjadinya pertumbuhan tanaman yang berbeda pula, karena hubungan antara jenis tanaman dengan mikroorganisme tanah dapat bersifat kompatibel jika senyawa dan asam organik yang dikeluarkan oleh tanaman sesuai dengan kebutuhan mikroorganisme tersebut. Penelitian ini sejalan dengan dengan penelitian Marliah et al., (2012) yang menunjukkan bahwa varietas tanaman yang berbeda akan menunjukkan pertumbuhan dan hasil yang berbeda walaupun ditanam pada kondisi lingkungan yang sama.

Irawati dkk. (2017) menyampaikan bahwa kemampuan cendawan endofit dalam memproduksi metabolit sekunder dari tanaman inangnya diduga disebabkan cendawan endofit mengalami rekombinasi genetik atau mengadopsi beberapa info genetik dari inangnya melalui suatu proses evolusi di dalam jaringan tanaman inang. Selanjutnya, Yuan et al. (2008) menyebutkan bahwa keberhasilan interaksi antara cendawan endofit dan inang menyiratkan adanya evolusi mekanisme regulasi secara mandiri yang unik dari kedua belah pihak.

Kombinasi K1C5 terinfeksi lebih cepat dibandingkan dengan kombinasi lainnya, namun kejadian penyakit tersebut menurun pada setiap pengamatan. Hal ini disebabkan jumlah daun tanaman kakao masih mengalami pertambahan daun sehingga persentase kejadian penyakitnya menurun seiring dengan waktu pengamatan. Diduga keberadaan cendawan endofit C5 mampu mempromosi pertambahan daun sehingga gejala gugur daun pada tanaman terinfeksi patogen VSD tidak terjadi. Fenomena ini mungkin dapat menjelaskan kemampuan cendawan endofit untuk memicu produksi fitohormon dan mempercepat diferensiasi jaringan dan organ tanaman. Hasil penelitian Taufik et al., (2019a) bahwa penggunaan cendawan endofit terbukti mampu menekan keajadian penyakit VSD pada tingkat pembibitan. Diuraikan lebih lanjut bahwa cendawan endofit Paecilomyces Ep1* yang diisolasi dari tangkai daun kakao mampu menghambat kejadian penyakit VSD $0 \%$ dibandingkan dengan kontrol $64 \%$ pada 8 minggu setelah inokulasi.

Hasil pengamatan kejadian penyakit VSD pada tanaman kakao menunjukkan bahwa rerata kejadian penyakit tertinggi diperoleh pada perlakuan COK2 yaitu kontrol pada klon 25 pada umur $20 \mathrm{MST}$ yaitu $5,75 \%$ dibandingkan dengan $\mathrm{C} 2 \mathrm{~K} 1, \mathrm{C} 3 \mathrm{~K} 1$, C6K1, C2K2, C3K2, C4K2, C5K2 dan C6K2. Gejala yang nampak seperti klorosis tampak daun menguning dengan bercak-barcak barwarna hijau. Biasanya daun tersebut terletak pada seri daun kedua atau ketiga dari titik tumbuh. Daun-daun yang menguning akhirnya gugur sehingga ranting kakao memiliki daun yang tidak utuh. Beberapa daun gugur sedangkan daun lainnya masih utuh sehingga nampak seperti daun yang ompong. Pada bekas duduk daun bila disayat terdapat tiga buah noktah berwarna coklat-kehitaman menunjukkan terjadinya kerusakan jaringan daun, dimana patogen VSD menginfeksi daun kakao dengan masuk ke lubang alami pada daun kakao (stomata). Iwaro et al. (1998) melaporkan bahwa stomata pada daun kakao bisa berfungsi sebagai lubang infeksi patogen penyakit. Penyakit VSD dapat menyebabkan kehilangan hasil sebesar $40 \%-50 \%$ bahkan dapat mematikan tanaman kakao produktif (Assad, 2017). Rendahnya kejadian penyakit VSD disebabkan penghitungan tingkat kejadian penyakit VSD hanya berdasarkan pada adanya gejala khas VSD pada tangkai daun kakao. Hasil ini mungkin akan berbeda jika dilakukan pengujian dengan menggunakan teknik deteksi molekuler misalnya.

Peluang untuk menggunakan klon kakao 45 dan 25 yang diberi cendawan endofit Paecilomyces sp. ataupun Trichoderma sp. dapat direkomendasikan untuk digunakan sebagai cara pengendalian VSD. Paecilomyces sp. adalah cendawan endofit yang mampu untuk menghasilkan giberelin phytohormones, peningkatan pertumbuhan tanaman oleh cendawan endofit yang diduga disebabkan juga oleh peningkatan jumlah akar rambut, percabangan akar rambut dan akar lateral, karena akar tanaman akan lebih luas dan lebih dalam. Vasudevan et al., (2002) melaporkan bahwa panjang akar pada suatu varietas dapat meningkat setelah cendawan endofit diterapkan. Akibatnya penyerapan nutrisi dan pertumbuhan tanaman akan lebih baik, lebih kuat dan lebih tahan terhadap penyakit. Penggunaan cendawan endofit di lapang efektif menekan penyakit VSD dalam kurung waktu yang cukup panjang dengan mengkombinasikan dengan residu bahan organik tanaman (Rosmana et al., 2019).

Kedua klon tersebut dapat terinfeksi secara alamiah oleh patogen VSD. Kondisi lapang memungkinkan terjadinya fenomena tersebut, karena kakao bergejala dijadikan sebagai sumber inokulum untu infeksi alami. Di lapang, basidiospora patogen disebarkan oleh angin dan menginfeksi daun-daun muda, cabang kemudian mengolonisasi jaringan xilem (Guest dan Keane 2007). Walaupun kedua klon dapat terinfeksi namun kedua klon yang diberi Paecilomyces sp.EP1, Paecilomyces sp.EP2 dan Paecilomyces sp.EP1 + Trichoderma sp tidak menunjukkan gejala VSD sampai akhir pengamatan 20 MST. Hal ini mungkin menunjukkan adanya pengaruh proteksi dari cendawan endofit yang diberi pada kedua klon kakao yang diuji di lapang. Masih diperlukan kajian lebih jauh untuk menjawab fenomena tersebut termasuk pola distribusi atau 
penyebaran penyakit VSD dari satu tanaman ke tanaman lain atau dari satu areal ke areal yang lain. Meskipun demikian hasil yang diperoleh memberikan harapan yang optimis di masa datang. Bahwa dengan menggunakan kombinasi klon kakao yang tahan atau toleran dengan cendawan endofit yang tepat dapat direkomendasikan untuk penyakit VSD di lapangan.

\section{KESIMPULAN DAN SARAN}

Berdasarkan hasil dan pembahasan maka

disimpulkan sebagai berikut:

1. Ada pengaruh interaksi antara klon kakao dengan isolat cendawan endofit terhadap pertambahan tinggi tanaman dan jumlah daun kakao.

2. Kombinasi C5K2 adalah kombinasi terbaik terhadap tinggi tanaman kakao, sedangkan (C4K1) adalah kombinasi terbaik terhadap jumlah daun kakao yang pada 20 MST.

3. Kedua klon kakao yang diuji (klon 45 dan 25) dapat terinfeksi alami oleh Ceratobasidium theobromae tanpa cendawan endofit (K1C0) dan (K2C0) dengan kejadian penyakit VSD 5, 21\% dan $5,75 \%$ secara berturut-turut. Kedua klon yang diberi cendawan endofit Paecilomyces sp.EP1, Paecilomyces sp.EP2 dan Paecilomyces sp.EP1 + Trichoderma sp tidak menunjukkan gejala VSD sampai akhir pengamatan 20 MST

\section{UCAPAN TERIMA KASIH}

Terima kasih disampaikan kepada Kemenristek Dikti atas dukungan Dana melalui Penelitian Terapan Unggulan Perguruan Tingg (PTUPT) T.A. 2018-2019. Dan terima kasih disampaikan kepada LPPM Universitas Halu Oleo atas dukungan selama kegiatan serta terima kasih disampaikan kepada mahasiswa dan petani yang membantu penelitian di lapang.

\section{DAFTAR PUSTAKA}

Assad M, Taufik M, Gusnawaty HS, \& Asniah. 2017. Isolation, identification, and the ability of endophytic fungi in stimulating cocoa seed germination. International Journal of Biosciences, IJB. 10(1): 270-278.

Aziz AI, Rosmana A, \& Dewi VS. 2014. Pengendalian penyakit hawar daun phytophthora pada bibit kakao dengan Trichoderma asperellum. J Fitopatol Indonesia. 9:15-20.

Badan Pusat Statistik. 2018. Produksi Kakao Sulawesi Tenggara Dalam Angka, 2016. https://sultra.bps.go.id/ Diakses pada tanggal 7 Mei 2019.

Clay K. 2004. Fungi and The Food of The Goods. Nature427:401402.Www.Biology.Duke.Edu/ News/Pdfs/Arnoldnandv.Pdf. Diakses pada tanggal 27 Juli 2016.

Direktorat Jenderal Perkebunan. 2015. Statistik Perkebunan Indonesia.2014-2016(Kakao). https://docplayer.info > 60496724-Statistik- perkebunan. Diakses pada tanggal 11

Oktober 2019.

Guest DI, \& Keane PJ. 2007. Vascular Streak Dieback: a new encounter disease of cacao in Papua New Guinea and South-east Asia caused by the obligate basidiomycete Oncobasidium theobromae. Phytopathology. 97:16541657.DOI:http://dx.doi.org/10.1094/ PHYTO-97-12-1654.

Hakkar AA, Rosmana A, Rahim MD. 2014. Pengendalian penyakit busuk buah Phytophthora pada kakao dengan cendawan endofit Trichoderma asperellum. Jurnal Fitopatologi Indonesia. 10 (5): 139-144.

International Cocoa Organization. 2017. Quarterly Bulletin of Cocoa Statistics. The International Cocoa Organization, Vol. XLIII, No. 2. Cocoa year 2016/17.

Irawati AFC, Mutaqin KH, Suhartono MT, Sastro Y, Sulastri \& Widodo. 2017. Eksplorasi dan Pengaruh Cendawan Endofit yang Berasal dari Akar Tanaman Cabai Terhadap Pertumbuhan Benih Cabai Merah. J. Hort. 27(1): 105-112.

Iwaro DAl, Sreenivasan TN, \& Umaharan P.1998. Cocoa resistance to Phytophthora: Effects of pathogen species, inoculation depths, and pod maturity. European J. Plant Pathol., 46: 557-565.

Ismail N, \& Tenrirawe A. 2011. Petensi agens hayati Trichoderma spp. sebagai agens pengendali hayati. Seminar Regional Inovasi Teknologi Pertaian, Mendukung Program Pembangunan Pertanian Provinsi Sulawesi Utara. Balai pengkajian teknologi pertanian (BPTP) Sulawesi Utara.

Kurniawan R, Pinem MI, \& Lisnawita. 2017. Pengaruh Pemberian Cendawan Endofit Asal Tanaman Kelapa Sawit Terhadap Pertumbuhan Kelapa Sawit pada Tanah Terinfeksi Ganoderma spp. Jurnal Agroekoteknologi. 56 : 462- 468.

Marliah N, Nurhayati dan Tarmizi. 2012. Effects of Mulch and Liquid Organic Fertilizer Super Bionik On Growth and Yield of Onion (Allium ascalonicum L.). Jurnal Floratek. 7: $164-172$.

Nono S, Wirianata H, \& Kristalisasi N. 2017. Pengaruh Ketahanan Beberapa Klon Kakao Terhadap Penyakit Busuk Buah (Phytophthora palmivora) dan Vascular Streak Dieback (Oncobasidium theobromae) pada Tanaman Kakao. Jurnal Agromast. 2(1) (Abstrak)

Palad MS, Ala A, Nasaruddin, \& Sennag N. 2016. Effectiveness Trichoderma asperellum on the Growth Cocoa Seeds under the Old Cocoa Trees. Modern Applied Science. 10 (11): 176-180. 
Pusat Perpustakaan dan Penyebaran Teknologi Pertanian. 2019. Hulu Hilir Kakao. Penerbit Pusat Perpustakaan dan Penyebaran Teknologi Pertanian. Bogor.

Rosmana A, Taufik M, Asman, Jayanti NJ, \& Hakkar AA. 2019. Dynamic of Vascular Streak Dieback Disease Incidence on Susceptible Cacao Treated with Composted Plant Residues and Trichoderma asperellum in Field. Agronomy2019, 9, 650. https://www. mdpi.com/journal/agronomy.

Sriwichai N, Phukhao A, Sakulmas N, Tasana T, \& Bussaban B. 2013. Production of Auxins and Gibberelins by Endophytic and Saprobic Fungi. Conference: Faculty of Science Exhibition, Chiang Mai University, Chiang Mai, Thailand. Affiliation: Chiang Mai University.

Taufik M, Boer D, Syair, Yusuf DN \& Putri NP. 2019a. The use of local endophyte fungus to control Vascular Streak Dieback (Ceratobasidium theobromae) disease in cocoa. Bioscience Research. 16(1):183-193.
Taufik M, Asniah, Yusuf DN, Syair, Boer D, \& Botek M. 2019b. Evaluating the ability of endophyte fungus to control VSD diseases in cocoa seeding. IOP Conf. Series: Earth and Environmental Science 382 : IOP Publishing doi:10.1088/1755-1315/382/1/012011.

Vasudevan P, Kavitha S, Priyadarsini VB, Babuje L, \& Gnanamanickam JJ. 2002. Pengendalian hayati penyakit padi. Dalam: Gnanamanickam SS, Editor. Biologis Pengendalian Penyakit Tanaman. New York. Basel: Marcel Dekker, Inc, pp 11-32.

Yuan ZL, Zhang CL, \& Lin FC. 2008. 'Recent advances on physiological and molecular basis of fungal endophyte-plant interactions'. Acta Eco. Sinica. 28(9):4439-30.

Wahab A, Wijayanto T, Taufik M, Bande LS, Gusnawatym Assaf M, Rahim MD, \& Firmansyah AP. 2016. Role of biological agents and cocoa clones to control vascular streak dieback disease (Ceratobasidium theobromae Tallbot and Keane) of cocoa plants. International Journal of Biosciences. 9 (3): 1-11. 